\title{
MONETARY TRANSMISSION OF PERSISTENT SHOCK TO THE RISK PREMIUM: THE CASE OF INDONESIA
}

\begin{abstract}
Akhis R. Hutabarat ${ }^{1}$
Abstract

This paper investigates the relative importance of monetary transmission channel to inflation of passing persistent shock to the risk premium. The findings show that nominal exchange rate depreciation, triggered by a more persistent shock to interest risk premium, worsens the state of the economy in the short- and long-run. Such distinctive shocks effect is transmitted through the economy that typifies lack of response of consumer price disinflation to interest rate tightening caused by high real rigidity, strong cost channel of interest rate, strong cost channel of exchange rate pass-through and weak demand-side channel of exchange rate pass-through. This study suggests a proper monetary policy response, which is the smallest interest rate increases within the feasible set of monetary policy responses that the model recommends, to minimize the adverse effects of the shocks.
\end{abstract}

JEL Classification: F41; E52; D58

Keywords: Exchange rate, Balance of Payment, Monetary transmission and policy, Dynamic General Equilibrium.

1 Senior Economist, Bank Indonesia, email: akhis@bi.go.id. This paper is mainly based on his research at the Department of Economics, University of Leicester between 2006 and 2008. The views expressed in the paper are the author 's own and do not necessarily reflect those of Bank Indonesia. 


\section{INTRODUCTION}

Adverse exchange rate shocks frequently hit Indonesia. Such particular shocks might occur in terms of frequent one time shocks or in a more persistent way during a longer period. The currency crisis that badly hit the country in 1997-1998 can be considered as a severe persistent shock to the risk premium that devalued the exchange rate and altered the economy's dynamic equilibrium. Invaluable lesson should be continuously learned to pursue better monetary management in anticipating possible recurrence of such crises. Better understanding of monetary transmission mechanism and its consequence to monetary policy limitation is therefore necessary and worthwhile.

Cost channel of monetary policy has been increasingly explored for the case of developed economies. Barth and Ramey (2001) provide empirical evidence for cost channel of monetary policy based on industry level data. Ravenna and Walsh (2006) shows that, if nominal interest rate adjustment directly affect real marginal cost, then interest rate policy directly affects inflation. They also show that any shock to the economy with the presence of the channel will generate a trade-off between stabilizing inflation and stabilizing output gap. Chowdhury, et al. (2006) applied a structural approach to find that the estimated direct cost effects of short-run nominal interest rates significantly contribute to the inflation dynamics in the majority of G7 countries. Agénor and Montiel (2008) noted that the interest rate cost channel has been proposed as an explanation of the "price puzzle" phenomenon, which was labelled by Eichenbaum (1992) referring to the existence of a positive correlation between increases in the short-term interest rate and the price level in Sims' (1992) empirical anomaly finding.

Existing empirical studies on Indonesia's monetary transmission compiled in Warjiyo and Juda Agung (2002) did not include cost channel of interest rate. However, the study, which employed VAR method, found "price puzzle" in response to monetary policy tightening. This phenomenon is usually linked to either VAR misspecification or the possible existence of a strong cost channel of monetary policy. As an emerging economy with relatively low labour productivity, it is likely that capital accumulation has been the main source of Indonesia's output growth.'Hossain (2006) estimated'a Cobb-Douglas production function to find that capital accumulation accounts for 60 percent source of growth in Indonesia for the last forty years. It is in the spirit of the Young (1995) paper that claimed that growth in East Asian countries was mainly driven by high rates of capital formation. Combined with higher lending rate, lower capital productivity, and lower wage than those in advanced economy, one can argue that capital share (capital owner's income as a fraction of GDP) is greater than the labour share ${ }^{2}$. This argument enhances the importance of investigating cost channel of monetary policy. 
This study uses a new Keynesian dynamic general equilibrium model of a small open economy involving four domestic economic players, namely the household, the firm-producer, the government, and the central bank, which interact with the foreign economy. The model characterizes the household's money-in-the-utility function and the firm's constant elasticity substitution production that employs labour, capital goods, and domestic and imported raw material. Interest rate policy is transmitted to the new Keynesian Phillips curve type of inflation through channels of aggregate demand, exchange rate pass-through, and cost of capital. I assume that the expectation channel of monetary policy is fully credible. It corresponds to agent's rational price expectation and perfectly credible monetary authority, which utilizes a simple interest rate policy rule contingent to the state of shock. Shock to interest rate risk premium is applied through a covered interest rate parity determination of exchange rate. The model is adapted and developed from optimizing models with staggered wage and pricessetting, which have been widely used in the literature on inflation and monetary policy ${ }^{3}$.

The model is employed to observe the effect of short term persistent shock to the risk premium on the performance of an economy, which is intended to be close to the structure and behaviour of Indonesia's economy. The focus of this study are the relative importance of monetary transmission channel that pass the shock and interest rate response to inflation and how monetary policy should respond optimally to the particular type and state of the shocks, given the distinctive monetary transmission.

This paper shows that nominal exchange rate depreciation triggered by persistent shocks to interest risk premium worsens the state of the economy in the short- and long-run. The shocks are transmitted through the economy characterizing lack of response of consumer price disinflation to monetary policy contraction resulted from high real rigidity, strong cost channel of interest rate, strong cost channel of exchange rate pass-through, weak demand-side channel of exchange rate pass-through, and weak aggregate supply channel of interest rate.

The study suggests a proper monetary policy response, which is the smallest interest rate increases within the feasible set of monetary policy responses that the model recommends, to minimize the adverse effects of the shocks. Other economic policies might be necessarily complementary to the limited span of monetary policy that can in turn help strengthening aggregate demand channel of interest rate. The most important one is policies that help reducing capital share of economy's output and consecutively could weaken the cost channel of interest rate.

\footnotetext{
2 According to Input-Output Table 2005, the share of return on equity in total value added is $64 \%$, while the employee 's salary contributes $34 \%$ of total value added.

3 See, for example, Ravenna and Walsh (2006), Christiano et al. (2005), Smets and Wouters (2003), Erceg and Levin (2003), Woodford (2003), and Murchison (2004). The first two incorporated interest cost channel for monetary policy.
} 
The organization of the rest of this paper is as follows. Section 2 presents a dynamic equilibrium model with prices and wage stickiness. Section 3 presents simulation scenarios, parameter calibration and model solution. Section 4 analyses simulation result. Section 5 concludes the study and infers some policy recommendations.

\section{THEORY}

This paper investigates the relative importance of monetary transmission channel to inflation of passing persistent shock to the risk premium. There are lots of literatures on this topic and one of the fast growing approach is the dynamic general equilibrium framework.

This study extends the dynamic general equilibrium model used and explained in detailed in Hutabarat (2007). This paper extends the model by incorporating interest-rate risk premium on foreign-denominated asset as a function of ratio of net foreign debt to GDP. Then, balance of payment block is developed that results in equations of current account, capital account, trade and service account, and net foreign asset. Moreover, I assume that the government also collects income tax on capital goods lessor's and the firm owner's dividend in addition to wage income tax in the previous model. I also change the Cobb-Douglas production technology with a constant elasticity of substitution technology to allow lower elasticities of factor inputs' demand with respect to input prices. The model's extension is described as follows.

\subsection{The Household}

The dynamic budget constraint is expressed in domestic currency's nominal and real terms as follows.

$$
\begin{gathered}
P_{t} c_{t}+\left(M_{t}^{d}-M_{t-1}^{d}\right)+\left(B_{t}^{H G}-B_{t-1}^{H G}\right)+\left(s_{t} B_{t}^{H^{*}}-s_{t-1} B_{t-1}^{H^{*}}\right)+P_{t}\left(k_{t}-(1-\delta) k_{t-1}\right) \\
\leq i_{t-1} B_{t-1}^{H G}+\widetilde{i}_{t-1}^{*} s_{t} B_{t-1}^{H^{*}}+P_{t}^{m} i m_{t}+\left(1-\tau_{t}\right)\left(W_{t} l_{t}+z_{t-1} P_{t} k_{t-1}+P_{t} \Pi_{t}\right) \\
c_{t}+\left(m_{t}^{d}-m_{t-1}^{d}\right)+\left(b_{t}^{H G}-b_{t-1}^{H G}\right)+\left(q_{t} b_{t}^{H^{*}}-q_{t-1} b_{t-1}^{H^{*}}\right)+\left(k_{t}-(1-\delta) k_{t-1}\right) \leq \\
-\frac{\pi_{t}}{1+\pi_{t}} m_{t-1}^{d}+r_{t-1} b_{t-1}^{H G}+\widetilde{r}_{t-1}^{*} q_{t-1} b_{t-1}^{H^{*}}+p_{t}^{m} i m_{t}+\left(1-\tau_{t}\right)\left(w_{t} l_{t}+z_{t-1} k_{t-1}+\Pi_{t}\right)
\end{gathered}
$$

Sources of household's revenues are income from supplying labour services (wages), selling imported goods, renting capital goods to the firm, owning firm (dividend) and selling the previous period's depreciated capital goods, as well as interest income on government bonds and foreign assets. 
I assume that the household's net foreign asset position is negative, $\left(B_{t}^{H^{*}}<0\right)$ meaning that the household is a net debtor of foreign asset. I further assume that foreign investors require a risk premium, $\kappa_{t}$, for the rate of interest, $i_{t}{ }^{*}$, of foreign currency-denominated loans they extend to the domestic household, so that $\left(1+i_{t}{ }^{*}\right)=\left(1+i_{t}{ }^{*}\right)\left(1+\kappa_{t}\right)$. Hence the principal and interest income from foreign asset is $\left(1+i_{t-1}^{*}\right)=\left(1+\kappa_{t-1}\right) s_{t} B_{t-1}^{H^{*}}<0$.

I follow Al-Eyd and Hall (2006), Murchison, et. al (2004), and Schmitt-Grohe and Uribe (2003) in defining the country-specific risk premium, $\kappa_{t}$, which depends on net foreign debtto-GDP ratio. The risk premium is also subject to a shock process, $\varepsilon^{K}{ }^{k}$, representing unforecastable changes in foreign investor's preferences on domestic assets.

$$
\kappa_{t}=\varsigma\left(e^{-\frac{s_{t} B_{t}^{*}}{P_{t} y_{t}}}-1\right)+\varepsilon_{t}^{\kappa}
$$

where $\varsigma$ is scaling parameter. The equation says that foreign asset interest-rate risk premium depends on net foreign debt, exchange rate, output, and exogenous shock to the risk premium. An increase in net foreign debt (or a decrease in net foreign asset) negatively affects the ability of domestic resident to repay the debt. Exchange rate depreciation increases the amount of domestic currency required to pay foreign debt and, in turn, worsens domestic resident's ability to repay their foreign debt. A declining real income worsens the economy's capability for foreign debt repayment. Risk premium on the foreign debt is absent when foreign asset equals foreign debt and negative if net foreign asset is positive. The later means that the domestic household can enjoy a lower-than-world interest rate for its foreign debt.

From the maximization of household utility function with respect to labour supply and consumption, we can find the real marginal cost of working of the form

$$
m c_{t}^{w}=\left(\frac{A_{t}^{\lambda(v-1)} c_{t}^{\sigma}\left(\alpha_{L} y_{t}\right)^{\lambda}}{1-\tau_{t}}\right)^{\frac{1}{\nu \lambda+1}}
$$

The household rents out capital goods to the firm with real rental rate of capital, $Z_{t}$, which is obtained by combining the first order condition of utility maximization with respect to real capital stock and nominal domestic bonds as follow

$$
z_{t}=\frac{r_{t}+\delta}{1-E_{t} \tau_{t+1}}
$$


Real rental price of capital that the household-lessor charges to the firm should cover real interest rate, depreciation rate of capital and the expected future income tax rate.

Real marginal cost of imports equals real import price equation when prices are fully flexible, which is equal to real exchange rate.

$$
m c_{t}^{m}=q_{t}
$$

Nominal exchange rate is obtained by combining the first order condition of the household's utility maximization with respect to nominal domestic and foreign bonds, which implies covered interest rate parity.

$$
s_{t}=E_{t} s_{t+1}\left(\frac{1+i_{t}^{*}}{1+i_{t}}\right)\left(1+\kappa_{t}\right)
$$

In order to obtain the household's financial assets and financial account, we can elaborate the equality of nominal budget constraint (1.2) by substituting the firm's real profit $\left(\Pi_{t}=y_{t}\right.$ - $\left.w_{t} l_{t}-p_{t}^{m} i m_{t}-z_{t-1} k_{t-1}\right)$, capital accumulation equation, $\left[k_{t}=(1-\delta) k_{t-1}+i v_{t}\right]$, and the decomposition of real investment as domestic and imported capital goods $\left(i v_{t}=i v_{t}^{d}+i m_{t}^{k g}\right)$. We can further substitute the decomposition of imported goods as finished goods, intermediate goods and capital goods $\left(i m_{t}=i m_{t}^{r m}+i m_{t}^{c g}+i m_{t}^{k g}\right)$, and take into account that domestic output, $y_{t^{\prime}}$ is supplied to the domestic household as consumption goods $\left(c_{t}^{d}\right)$, to the firm as additional capital goods $\left(i v_{t}^{d}\right)$, to the government as consumption and invest ment goods $\left(g_{t}\right)$, and to the foreign importers as exported goods $\left(x_{t}\right)$. These substitutions result in the household's dynamic real budget constraint that can be rearranged to get the household's real financial assets of the form

$$
b_{t}^{H}=\left(x_{t}-q_{t} i m_{t}\right)+g_{t}+\left[\left(1+r_{t-1}\right) b_{t-1}^{H G}+\left(1+r_{t-1}^{*}\right)\left(1+\kappa_{t-1}\right) q_{t} b_{t-1}^{H^{*}}\right]-\tau_{t} y_{t}-\left(m_{t}^{d}-\frac{m_{t-1}^{d}}{1+\pi_{t}}\right)
$$

where $b_{t}^{H}$ is the household's real financial investment on the government bonds and foreign bonds in period $t$. It is equal to their net real revenues as exporter and importer and as the supplier of goods to the government, plus the principal and interest real income from the previous period's financial investment, minus real income tax expenditure and changes in real money holding. 


\subsection{The Firm-Producer}

The firm produces output using a Constant Elasticity of Substitution (CES) production technology that utilizes labour, capital, and foreign and domestically produced intermediate goods as production input. The aggregate real output of the economy follows Murchison et al. (2004) to take the form

$$
y_{t}=\left(\alpha_{L}^{\frac{1}{v}}\left(A_{t} l_{t}^{d}\right)^{\frac{v-1}{v}}+\alpha_{K} \frac{1}{v}\left(u_{t} k_{t-1}\right)^{\frac{v-1}{v}}+\alpha_{M^{\frac{1}{v}}}\left(\mathrm{im}_{t}^{r m}\right)^{\frac{v-1}{v}}\right)^{\frac{v}{v-1}}
$$

where $\alpha_{L}, \alpha_{K}, \alpha_{M}$ are labour, capital and import share, respectively, which are assumed to be constant and forms a constant return-to-scale technology of production, and $v$ is the elasticity of substitution between factor inputs. The objective of the firm is to choose the level of factor inputs that maximize its present discounted values of lifetime real profit, which is the deviation of total real revenues from total real cost.

$$
\Pi_{t}=\left(\alpha_{L^{\frac{1}{v}}}\left(A_{t} l_{t}^{d}\right)^{\frac{v-1}{v}}+\alpha_{K^{\frac{1}{v}}}\left(u_{t} k_{t-1}\right)^{\frac{v-1}{v}}+\alpha_{M^{\frac{1}{v}}}\left(i m_{t}^{r m}\right)^{\frac{v-1}{v}}\right)^{\frac{v}{v-1}}-w_{t} l_{t}^{d}-p_{t}^{m} i m_{t}^{r m}-z_{t-1} k_{t-1}
$$

Employment equation is given by the first order condition with respect to labour demand

$$
l_{t}^{d}=\frac{\alpha_{L} A_{t}^{v-1} y_{t}}{w_{t}^{v}}
$$

From the first order condition of the firm's profit maximization, we can obtain the demand for the imported intermediate goods of the form

$$
i m_{t}^{r m}=\frac{\alpha_{M} y_{t}}{p_{t}^{m^{v}}}
$$

The firm's stock of capital goods required for production is obtained from the first order condition of the firm's profit maximization with respect to capital:

$$
k_{t}=\frac{\beta \alpha_{K} E_{t} u_{t+1}^{{ }^{\nu-1}} E_{t} y_{t+1}}{z_{t}{ }^{v}}
$$


Real marginal cost of producing goods is derived from the firm's real cost minimization problem in which the aggregate firm chooses the level of factors inputs that minimize total real cost, $t c_{t}=w_{t} l_{t}+p_{t}^{m} i m_{t}^{r m}+z_{t-1} k_{t-1}$, subject to CES production function (9). The aggregate firm's real marginal cost, $m c_{t}^{d}$, is expressed as a function of real wage, real rental price of capital, real import price and the level of technology of the form:

$$
\left.m c_{t}^{d}=\frac{w_{t}}{A_{t} \alpha_{L^{v-1}} \frac{1}{\alpha_{L}}}\left(1+\frac{1}{A_{t}}\right)^{v-1}\left(\alpha_{K}\left(\frac{u_{t}}{z_{t-1}}\right)^{v-1}+\alpha_{M}\left(\frac{1}{p_{t}^{m}}\right)^{v-1}\right)\right)^{-\frac{1}{v-1}}
$$

The new Keynesian Phillips curve in deviation from steady-state follows Calvo's staggered price setting mechanism (Calvo, 1983).

$$
\hat{\pi}_{t}^{d}=\beta E_{t} \hat{\pi}_{t+1}^{d}+\left(\frac{(1-\theta)(1-\beta \theta)}{\theta}\right) m \hat{c}_{t}^{d}
$$

where, $\pi_{t}^{d}=\ln P_{t}^{d}-\ln P_{t-1}^{d}, \pi_{t}^{d}=P_{t}^{d}-P_{t-1}^{d}$ and $\theta$ is degree of domestically-produced goods price stickiness.

Replacing real marginal cost with the discrepancy between actual output and natural output (output gap) is inappropriate in dynamic general equilibrium model since output gap ( $y_{t}$ $\left(y_{t}^{n}\right)$ in such model is not a measure of business cycle that can be linked to the movement of real marginal cost. Natural output is the level of output that would prevail if nominal rigidities are absent in the economy. For example, Clarida, et al. (1999, p. 1665) define the "natural level of output" as "the level of output that would arise if wages and prices were perfectly flexible." We can interpret natural output as the output that corresponds to the condition where all firms act competitively by setting their price at nominal marginal cost, implying a constant unit markup. Natural output $\left(y_{t}^{n}\right)$ in dynamic general equilibrium model does not stand for trend level of actual output in monopolistically competitive market with nominal rigidity.

\subsection{The Fiscal Authority}

Government expenditure is financed through collecting income tax on the importer's, capital goods lessor's, and firm owner's dividend or issuing domestic-and foreign-denominated bonds. The government's nominal dynamic budget constraint is expressed as

$$
B_{t}^{G H}+s_{t} B_{t}^{G^{*}}+\tau_{t} P_{t} y_{t}+M_{t}^{s}-M_{t-1}^{s}=\left(1+i_{t-1}\right) B_{t-1}^{G H}+\left(1+i_{t-1}^{*}\right)\left(1+\kappa_{t-1}\right) s_{t} B_{t-1}^{G^{*}}+P_{t} g_{t}
$$


where $B_{t}^{G}=B_{t}^{G H}+s_{t} B_{t}^{G^{*}}$ is government revenue from issuing domestic bonds $\left(B_{t}^{G H}\right)$ and foreign bond $\left(B_{t}^{G^{*}}\right), \tau_{t} P_{t} y_{t}$ is tax revenue, $\left(M_{t}^{s}-M_{t-1}^{s}\right)$ is seignorage revenue, $g_{t}$ is real government spending, and is nominal exchange rate. The government real debt, which comprises its debt to the household and to the foreign economy, $b_{t}^{G}=b_{t}^{G H}+q_{t} b_{t}^{G^{*}}$, takes the form

$$
b_{t}^{G}=g_{t}+\left(\left(1+r_{t-1}\right) b_{t-1}^{G H}+\left(1+r_{t-1}^{*}\right)\left(1+\kappa_{t-1}\right) b_{t-1}^{G^{*}} q_{t}\right)-\tau_{t} y_{t}-\left(m_{t}^{s}-\frac{m_{t-1}^{s}}{1+\pi_{t}}\right)
$$

Fiscal policy rule takes the form of tax rate reaction function that ensures the sustainability of fiscal balance. The government's objective is to achieve and maintain a fixed ratio of primary fiscal deficit-to-GDP.

$$
\tau_{t}=\tau_{t-1}+\Theta\left(\frac{g_{t}-\tau_{t} y_{t}}{y_{t}}-\psi\right)
$$

where $\tau_{t}$ is tax rate policy response, $g_{t}$ is real government consumption, $y_{t}$ is real output, $\Theta$ is fiscal policy response parameter, and $\psi$ is a constant parameter representing the target of real primary fiscal deficit-to-GDP ratio.

\subsection{Real Net Foreign Debt and Financial Account}

Real net foreign debt, $d_{t}^{*}$, is obtained from the household's and the government's real budget constraints. It is used to finance trade deficit and repay the previous period's foreign debt.

$$
d_{t}^{*}=\left(i m_{t}-x_{t} / q_{t}\right)+\left(1+r_{t-1}^{*}\right)\left(1+\kappa_{t-1}\right) d_{t-1}^{*}
$$

Financial account (foreign debt flow), $F A_{t}$, is the total of changes in the government's net foreign debt and changes in the private sector's net foreign debt. We can get the national debt flow from the household and the government's nominal budget constraints by assuming that government's domestic debt equals the household's holding on government bonds, that foreign residents do not hold government domestic-denominated bond ( $B_{t}^{G H}=B_{t}^{H G}$ ), and the equilibrium of money holds.

$$
F A_{t}=\left(P_{t}^{*} i m_{t}-P_{t} x_{t} / s_{t}\right)-\left[\left(1+i_{t-1}^{*}\right)\left(1+\kappa_{t-1}\right)-1\right] B_{t-1}^{*}
$$




\subsection{The Goods Market Equilibrium}

The equilibrium of goods market is defined by resource constraint that equate the aggregate demand for output with the aggregate supply of output (2.1) of the form

$$
c_{t}+g_{t}+i v_{t}+x_{t}-i m_{t}=\left(\alpha_{L^{\frac{1}{v}}}\left(A_{t} l_{t}^{d}\right)^{\frac{v-1}{v}}+\alpha_{K^{\frac{1}{v}}}\left(u_{t} k_{t-1}\right)^{\frac{v-1}{v}}+\alpha_{M^{\frac{1}{v}}}\left(i m_{t}^{r m}\right)^{\frac{v-1}{v}}\right)^{\frac{v}{v-1}}
$$

\subsection{The Monetary Policy}

The central bank is implicitly part of the government that supply money to the household through government consumption. Thus, bank lending channel is nonexistent in this model. The central bank affects inflation through aggregate demand, aggregate supply, exchange rate, and cost channel of interest rate policy. It employs a forward-looking Taylor-type interest rate policy rule as defined in Clarida, et al. (1999). It is a short term nominal interest rate response to the forecast of next period inflation gap, which is the deviation of the forecast of future inflation from its inflation target, while also taking into account the smoothness of interest rate movement.

$$
i_{t}=\chi i_{t-1}+(1-\chi)\left[\bar{r}+\bar{\pi}+\alpha_{\pi}\left(\pi_{t+1}-\pi_{t+1}^{T}\right)\right]
$$

where $\bar{r}$ is the steady-state level of real interest rate and $\pi_{t}^{T}$ is inflation target path at period $t, \chi$ is interest rate smoothing parameter, and $\alpha_{\pi}$ is monetary policy response parameter.

Monetary policy does not respond to discrepancy between actual output and natural output (output gap). If monetary policy responds to such measure of output gap it aims to achieve the flexible price level of output under perfectly competitive goods market, which is higher than the trend of actual output under monopolistically-competitive market with inflexible price $\left(y_{t}^{n}>y_{t}\right)$. If monetary authority achieves the target of natural output, it will tend to conduct an inflationary-biased policy because it could continuously generate accelerating inflation $\left(\pi_{t}>E_{t} \pi_{t}\right.$ ), given zero average value of supply shocks (Sorensen et al., 2005). By using policy rule that only respond to inflation gap, it is assumed that monetary policy does not only aim to achieve inflation target directly but also the target of output indirectly. However, the target of output for stabilization policy provided by new Keynesian Phillip curve is the trend level of actual output $\left(\widetilde{y}_{t}\right)$. 
Interest rate policy is passed-through to aggregate demand via three transmission channels. First, real interest rate affects consumption through substitution and income effect. Second, real interest rate determines capital goods procurement cost hence influence demand for investment. Third, policy rate has an effect on nominal exchange rate and then is transmitted to real exchange rate as a determinant of foreign demand for domestic good. The latter is also called as monetary transmission through indirect pass-through effect of exchange rate.

Monetary policy is transmitted to consumer inflation through three channels. First, aggregate demand channel of interest rate policy is passed-through to domestic inflation through changes in wages and profit margin. The second channel is interest cost of production channel, which is specifically the interest rate cost of procuring capital goods, either financed by equity or loan capital ${ }^{4}$. Third, monetary policy affects consumer inflation through two exchange rate channels. The first one is through the cost of imported intermediate goods in domestic prices and the other one is through consumption imported-goods inflation. They are named intermediate and immediate direct pass-through effect of exchange rate to consumer price, accordingly.

\section{METHODOLOGY}

\subsection{Model Solution Method}

This study solved the static steady-state and the linearised dynamic model in deviation from steady-state using CONOPT solver under GAMS system. This solver employs Generalized Reduced Gradient method of solution for nonlinear programming problems (Rosenthal, 2006 and Drud, 2006), defined as:

min or max $\quad f(\mathbf{z})=\mathrm{J}=0$ (performance index)

subject to vector of implicit log-linear functions

$$
g(\boldsymbol{z})=g_{t}\left(\mathbf{y}_{\mathbf{t}-\mathbf{1}}, \mathbf{y}_{\mathbf{t}}, \mathbf{y}_{\mathbf{t}+\mathbf{1}}, \mathbf{x}_{\mathbf{t}} ; \boldsymbol{\theta}, \overline{\mathbf{y}}, \overline{\mathbf{x}}\right)=\left[\begin{array}{c}
g_{1, t}\left(\mathbf{y}_{\mathbf{t}-\mathbf{1}}, \mathbf{y}_{\mathbf{t}}, \mathbf{y}_{\mathbf{t}+\mathbf{1}}, \mathbf{x}_{\mathbf{t}} ; \boldsymbol{\theta}, \overline{\mathbf{y}}, \overline{\mathbf{x}}\right) \\
\vdots \\
g_{m, t}\left(\mathbf{y}_{\mathbf{t}-\mathbf{1}}, \mathbf{y}_{\mathbf{t}}, \mathbf{y}_{\mathbf{t}+\mathbf{1}}, \mathbf{x}_{\mathbf{t}} ; \boldsymbol{\theta}, \overline{\mathbf{y}}, \overline{\mathbf{x}}\right)
\end{array}\right]=\mathbf{0}
$$

$\boldsymbol{l}<\boldsymbol{z}<\boldsymbol{u}$

\footnotetext{
4 The interest cost of equity capital channel can also be named "firm's profitability channel". The model assumes that changes in interest rate is fully and symmetrically passed-through in the short run to the cost of equity capital, causing profit margin adjusts as well. The inclusion of cost of equity in the interest cost channel relies on two implied assumptions. First, that the firm's loan-to-equity ratio in Indonesia's nonfinancial business units is lower than that in developed economies. Second, that the firm's market power in the former economy is stronger than in the later, causing the likelihood to have the rate of return on equity greater than interest rate cost of equity. It is in line with the view of Chowdhury et al. (2006) that the logic of interest rate effects on firms' costs also applies when firms are primarily financed by internal funds.
} 
where $z$ is vector of optimization variables, $l$ and $u$ are vectors of lower and upper bounds, some of which may be minus or plus infinity, and $f$ and $g$ are differentiable nonlinear functions that define the model. Constraint (6.2) is general constraints and (6.3) is boundary of variables.

The objective function $f$ is the variable to be minimized or maximized; $m$ is the number of equations and $n$ denotes number of variables. Vector $z$ consists of $y_{t-1}, y_{t}, y_{t+1}$ and $x_{t^{\prime}}$ which are vector of endogenous lag variables, endogenous contemporaneous variables, endogenous lead variables and predetermined exogenous variables, accordingly. $\theta$ is vector of parameter, $\bar{y}$ is vector of steady-state values of endogenous variables, and $\bar{x}$ is vector of steady-state values of exogenous variables. For $T$ solution period, the implicit equations for all period are stacked to have a system containing $M=m T$ equations and $N=n T$. variables.

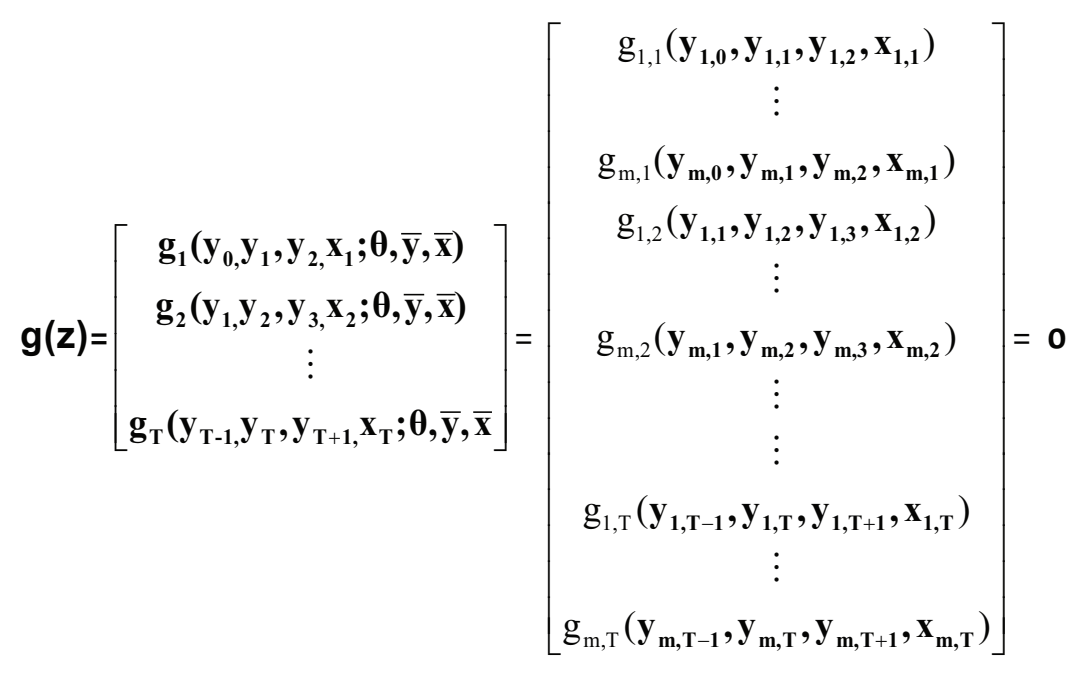

Where $y_{0}$ and $y_{T+1}$ are vector of endogenous lag variables at $t=1$ and vector of endogenous lead variables at $\boldsymbol{t}=\boldsymbol{T}$, accordingly, which are pre-determined at steady-state values.

\subsection{Simulation Scenario and Parameter Setting}

I conduct a simulation by applying an eight-quarter one percentage point positive exogenous shocks to the risk premium equation. The type, magnitude and length of shock are meant to resemble a moderate currency crisis. The simulation objective is to evaluate the effect of such shocks on economic performance, in particular the exchange rate, balance of payment and monetary policy response. By applying one single type of shock, it is implicitly assumed that other kinds of shocks are not present and the economy is not pursuing disinflation. 
I apply shock simulation to the log-linearised version of the model in deviation from steady-state values. As the lag dependent variables take their steady-state values, it means the shocks simulatedly occur in the steady-state of the economy, in which the level of real variables and growth variables, i.e. inflation, are constant, and the level of nominal variables grows at nonzero constant rates. Hence we need to interpret the simulation result for the actual shocks that occur in the economy before the steady-state, in which the level of real and nominal variables can grow at nonzero rates and the level of growth variables are not necessarily constant.

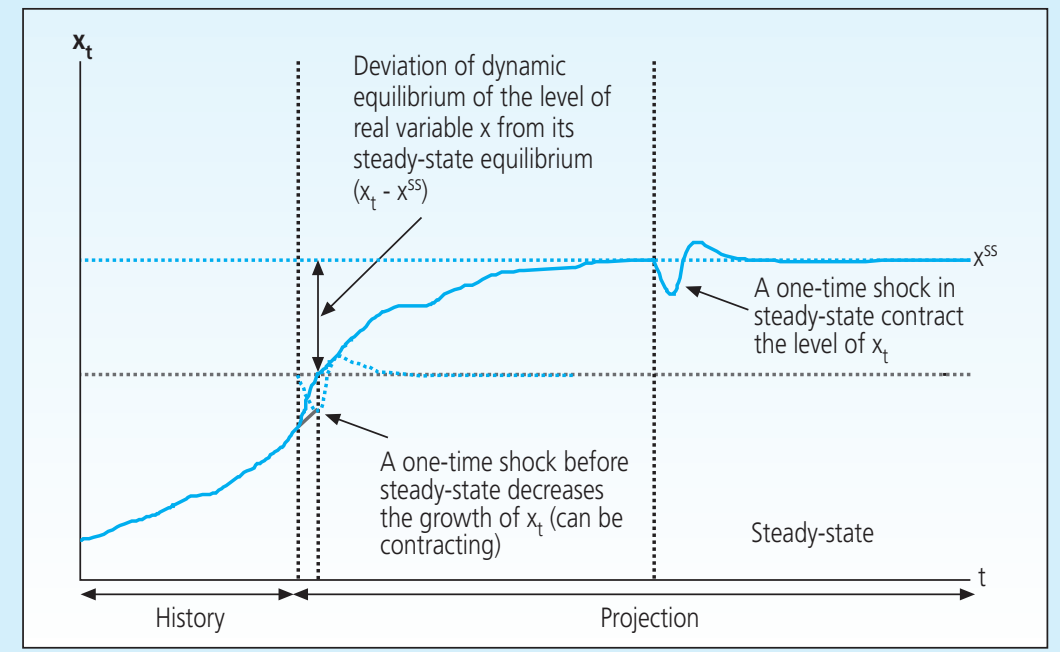

Figure 1.

Illustration of shock simulation to a real variable

When we apply a one-time shock in steady-state, the resulted deviation of a real variable from its constant steady-state equilibrium value means either an expansion or a contraction of the level of such real variable. However, when the shock occurs in dynamic state of the economy, which is before steady-state, it will generally result in either an accelerated or a decelerated level of a real variable except that the magnitude of shock is large enough to contract real variables. Therefore, one may interpret an expansion or a contraction of a real variable in steady-state as an increasing or a decreasing growth of a real variable before steady-state. Figure 1 illustrates the interpretation of the contraction effect on a given real variable of a onetime simulated shock in steady-state. We can infer similar interpretation for a nominal variable in the case of a one-time shock, in steady-state (Figure 2). Meanwhile, the interpretation of the effect on a growth variable of a one-time shock in steady-state is the same with of a one-time actual shock before the steady-state. 


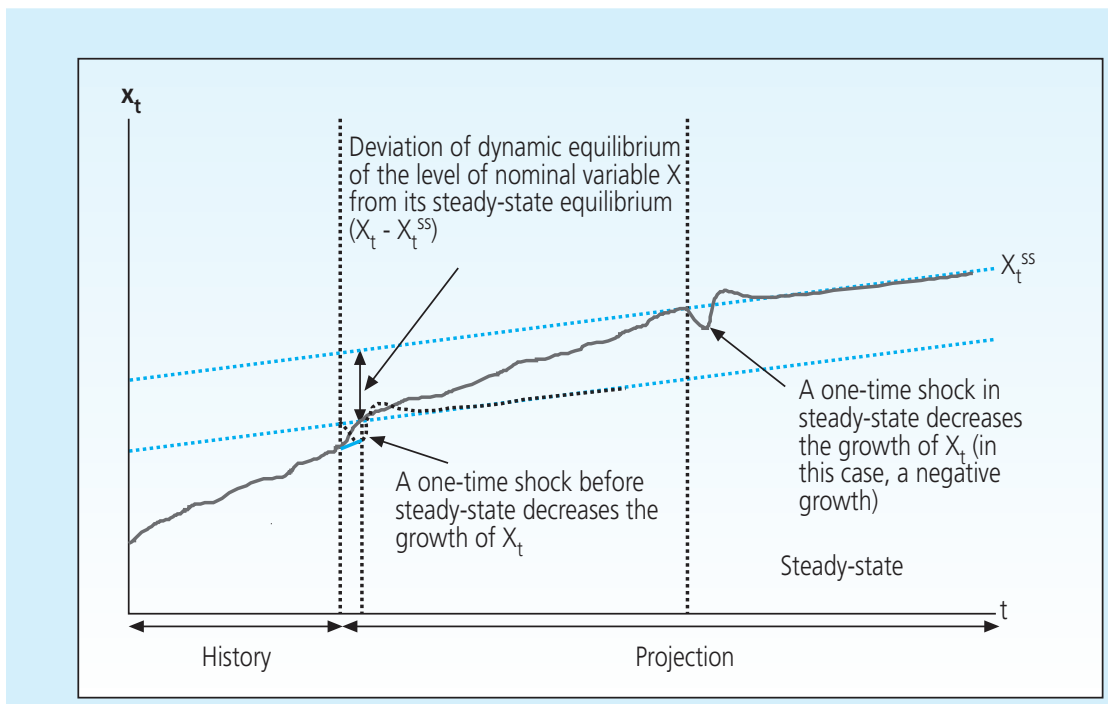

Figure 2.

Illustration of shock simulation to a nominal variable

Table 1 exhibits parameter calibration. The firm's, importer's and wage setter's future profits are discounted at discount factor $\beta=0.99$. From consumption Euler equation, we get the steady-state real interest rate that equals the household's rate of time preference. Setting real interest rate at 0.02 corresponds to the household discount factor, $\boldsymbol{\vartheta}$, at 0.98 . The economy's structure of output and demand for output are assumed to aproximately follow current figures. The share of capital goods, labour and imported intermediate goods in the aggregate output of the economy are set at $\alpha_{K}=0.5, \alpha_{L}=0.35$, and $\alpha_{M}=0.15$.

Government spending-to-GDP ratio is set at $\alpha_{g}=0.18$ and export-to-GDP ratio at. The share of imported consumption good in total consumption, $\alpha_{m c g}$, and imported capital goods in total investment, $\alpha_{m k g}$, are both 0.14 . The share of government bond in household's assets, $\alpha_{H G}$, is assumed equals 0.5 , and the share of domestic debt in government liabilities, $\alpha_{G H}$, is 0.6. The ratio of debt to GDP in steady-state is $20 \%$.

I set the real consumption intertemporal elasticity of substitution at $\sigma^{-1}=0.004$. This low substitution effect assumption is inline with the findings in Kusmiarso et al. (2002) that impliedly indicated the presence of strong income effect. Their study on interest rate channel of monetary transmission using VAR found that an increase in interest rate is initially responded by a negative growth of consumption. However, household consumption follows to decrease when interest rate starts to decrease. Nominal interest rate elasticity of real money holding is 


\begin{tabular}{|c|c|c|}
\hline \multicolumn{3}{|c|}{$\begin{array}{c}\text { Table } 1 . \\
\text { Model Calibration }\end{array}$} \\
\hline Parameter & Deskripsi & Nilai \\
\hline$\vartheta$ & the household's discount factor & 0.98 \\
\hline$\beta$ & the firm's, importer's and wage setters' discount factor & 0.99 \\
\hline$\sigma^{-1}$ & consumption intertemporal elasticity of substitution & 0.004 \\
\hline$\rho^{-1}$ & nominal interest rate elasticity of real money holding & 0.008 \\
\hline$\lambda^{-1}$ & real wage elasticity of labour supply & 0.015 \\
\hline$\delta$ & depreciation rate of capital & 0.01 \\
\hline$v$ & elasticity of substitution between factor inputs & 0.3 \\
\hline$\alpha_{K}$ & capital share & 0.5 \\
\hline$\alpha_{L}$ & labour share & 0.35 \\
\hline$\alpha_{M}$ & imported intermediate goods share & 0.15 \\
\hline$\alpha *_{M}$ & share of domestic country's export in the rest of the world's total demand & 0.00018 \\
\hline$\alpha_{m c g}$ & share of imported consumption good & 0.14 \\
\hline$\alpha_{m k g}$ & share of imported capital goods investment & 0.14 \\
\hline$\alpha_{g}$ & ratio of government expenditure-to-output & 0.08 \\
\hline$\alpha_{x}$ & ratio of exports-to-output & 0.28 \\
\hline$\eta$ & real exchange rate elasticity of exports & 0.2 \\
\hline$\theta$ & degree of price stickiness & 0.35 \\
\hline$\theta^{m}$ & degree of import price stickiness & 0.1 \\
\hline$\theta^{w}$ & degree of wage stickiness & 0.75 \\
\hline$\gamma^{w}$ & degree of wage indexation to lag inflation & 0.9 \\
\hline$\psi$ & target of fiscal deficit ratio & $2 \%$ \\
\hline$\chi$ & degree of interest rate inertia & 0.5 \\
\hline$\alpha_{\pi}$ & monetary policy response parameter & large \\
\hline$\Theta$ & fiscal policy response paramater & 0.5 \\
\hline$\varsigma$ & scaling parameter of risk premium & 0.00000001 \\
\hline$\alpha_{H G}$ & share of government bond in household's assets & 0.5 \\
\hline$\alpha_{G H}$ & share of domestic bond in government liabilities & 0.6 \\
\hline
\end{tabular}

set at $\rho^{-1}=0.008$, reflecting a lower degree of cashless economy than in developed countries. Real exchange rate elasticity of exports is set at $\boldsymbol{\eta}=0.2$ in accordance with the associated coefficient in BI's macroeconometric model. I calibrate the real wage elasticity of labour supply at $\lambda^{-1}=0.002$. This value is much lower than the elasticity in developed economies commonly used in related research. This reflects a labor market that is characterized by low real wage income, excess supply of labour and low appreciation for leisure time. The constant elasticity of substitution between factor input is set at $v=0.3$.

Degree of price rigidity of domestically-produced goods, $\theta$, is set at $0.35 \mathrm{implying}$ that the average time between domestic price adjustment is about one and a half quarters. Domestic 
price of imported goods is assumed less rigid than domestically-produced goods $\left(\theta^{m}=0.1\right)$, implying that the average duration of import price is 3.3 months. In setting rigidity parameter, I refer to business price setting survey for Indonesia's economy in Darsono et al. (2002), which found that manufacturing goods prices stay an average of 4.6 months and that exchange rate changes is passed-through to import price in the same quarter. Wage rigidity is assumed at $\theta^{w}$ $=0.75$, corresponding to yearly nominal wage changes. However, the refference for wage changes is heavily based on the previous wage inflation rather than on forward looking optimal price setting. This behaviour is reflected in parameter $\gamma^{w}$ that is equal to 0.9.

Inflation feedback parameter in the simple interest rate rule is set at a value that minimizes present discounted value of dynamic welfare loss over a hundred quarters after the shock. The loss function is symmetric of the form, $L=E_{t} \sum_{s=0}^{\infty} \beta_{L}{ }^{s}\left(\left(\pi_{t+s}-\bar{\pi}\right)^{2}+\left(y_{t+s}-\bar{y}\right)^{2}\right)$ where monetary policy makers have equal preferences on both inflation and output stabilization. Inflation feedback coefficient is contingent on the magnitude and extent of a shock to the risk premium. I search the optimal policy feedback coefficient by fixing interest rate smoothing coefficient at $\chi=0,5$, reflecting equally backward- and forward-looking behaviour of monetary authority in formulating interest rate policy.

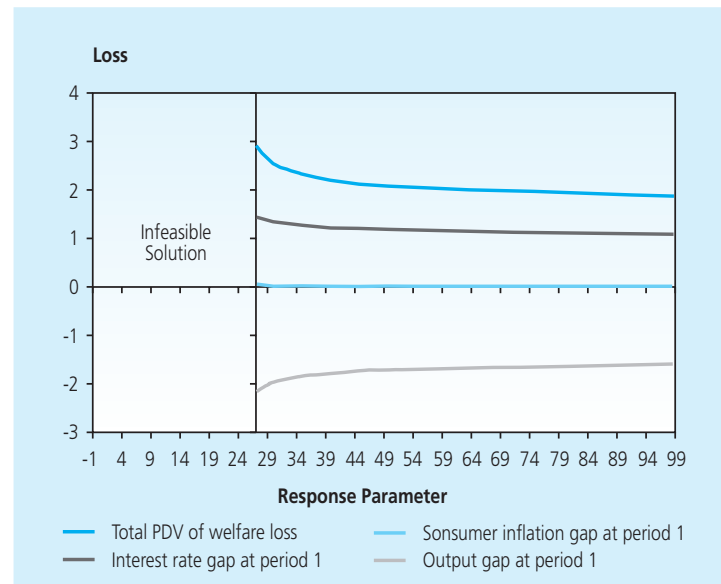

Figure 3.

Range of Feasible Response Parameter

Figure 3 shows range of feasible inflation feedback parameters when interest rate responds to a future period's inflation gap.'The figures show that the feasible set of the monetary authority response to the risk premium shock is a rising interest rate. 
However, the optimal response, which produces the lowest inflation effect and the smallest short-run output contraction, is the smallest interest rate increases within the feasible set. The highest interest rate increase in the set corresponds to the most nonoptimal response. Whenever applies, the optimized responses are depicted on dashes line on the graphics.

\section{RESULT AND ANALYSIS}

\subsection{Exchange Rate and Balance of Payment}

Figure 4-5 and Figure 7-14 exhibit the responses economic variables to an eight-quarter one percentage point shock to the risk premium. Nominal exchange rate contemporaneously depreciates as a response to risk premium shock, but its extent is lowered by immediate interest rate response. The rate of nominal exchange finally achieves a new, weaker steady-state level when the nominal rate of interest returns to and stabilizes at the initial rate, leaving expectation channel works solely. The long run equilibrium of nominal exchange rate becomes weaker to compensate a lower relative price of foreign to domestic goods so that real exchange rate is unchanged in the long run.
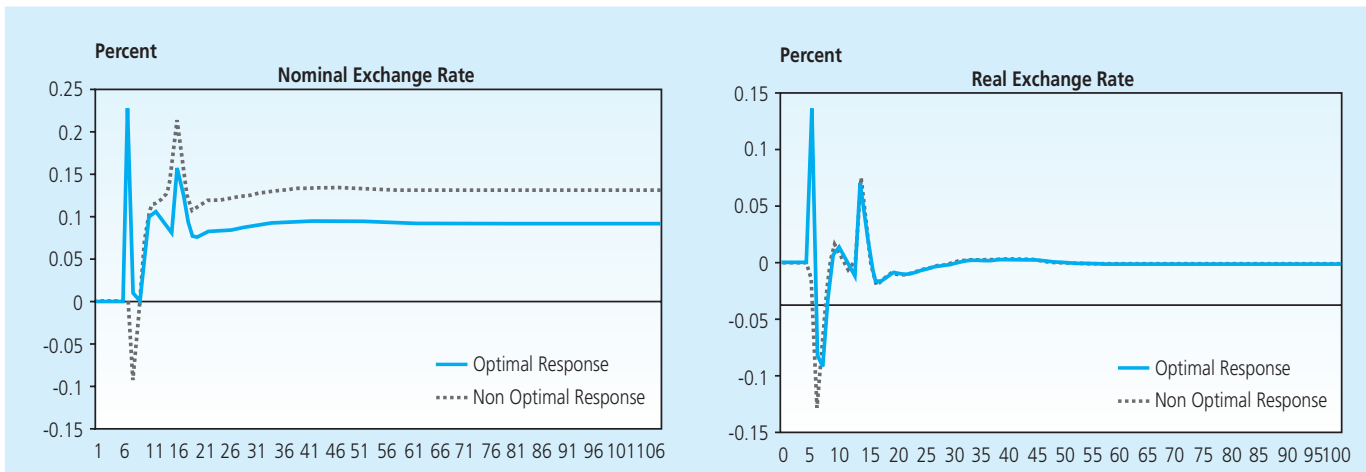

Figure 4. Responses of the exchange rate to an eight-quarter one percentage point shock to the risk premium

(percent or percentage point deviation from baseline initial steady-state)

Real export follows real exchange rate movement in the absence of changes to foreign demand. With a low elasticity of real export with respect to real exchange rate, real export only moves up by about $0.027 \%$. It then falls below initial steady-state when real exchange rate strengthens several quarters after the shock. Exports returns to its initial steady-state level in the long run. 

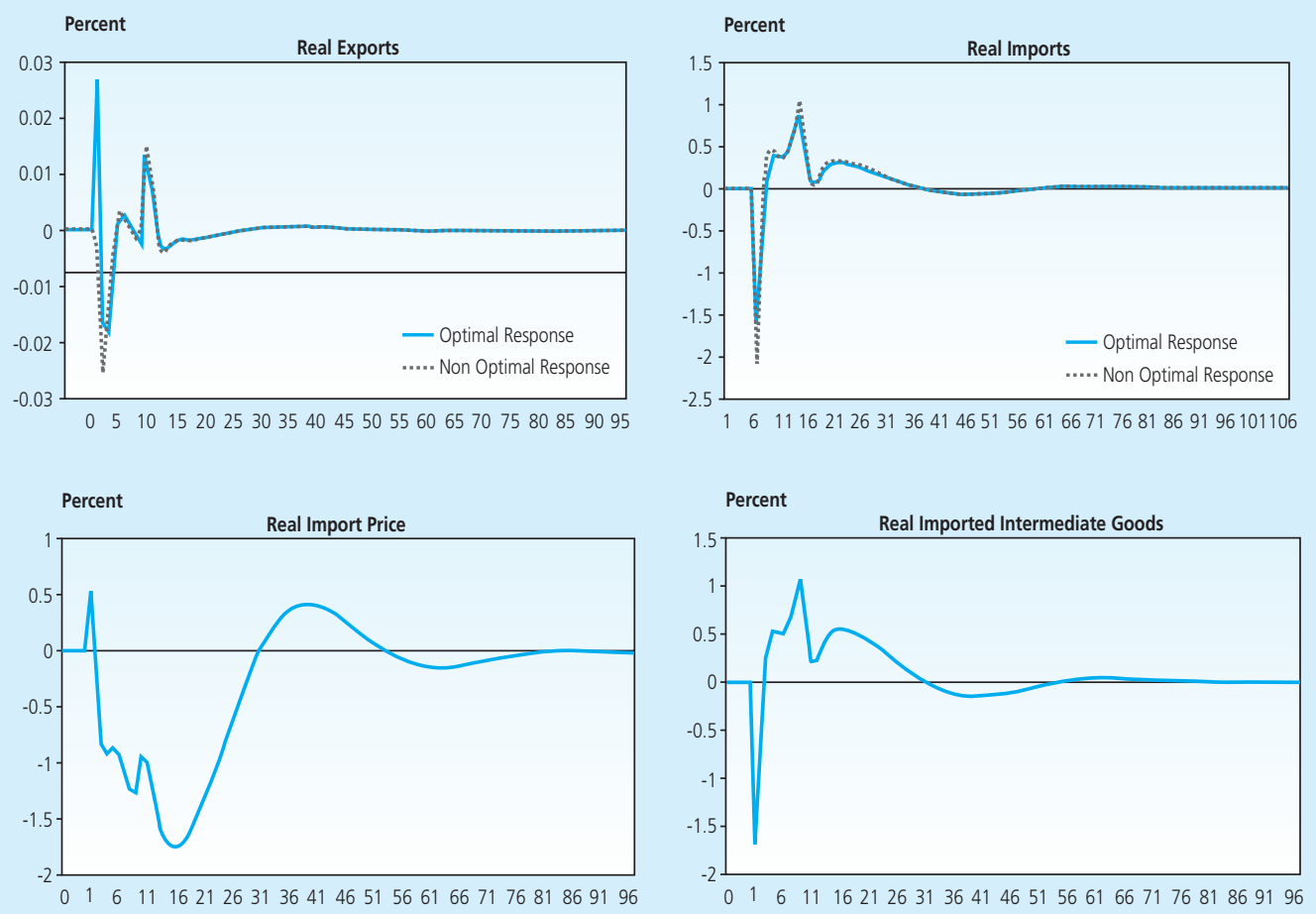

Figure 5. Responses of export and import to an eight-quarter one percentage point shock to the risk premium

(percent or percentage point deviation from baseline initial steady-state)

Following an increase in real import price, real import falls by about 1.6\%, much larger than an increase in real exports in the early period of shocks. Foreign price value of imports declines sharply since foreign price quarterly inflation stays the same. On the other side, foreign price value of exported goods also declines accordingly as nominal exchange rate depreciates more than an increase in real export and consumer price. The net effect is a huge jump in trade surplus, exhibiting an inverted J-curve phenomenon. Indonesia's trade surplus and real exports and imports in the period of currency crisis justify the simulation result, to some extent, in terms of direction of related variables. Figure 6 shows that in the aftermath of currency crisis in 1998, when nominal exchange rate depreciated by $123 \%$, real exports expanded $11.2 \%$ and real imports contracted $2.9 \%$, resulted in $83 \%$ trade surplus increases.

This result is in line with an empirical study on J-curve effect. Using a VECM model on the quarterly data of Indonesia and its trading partners, Husman (2005) concluded that J-curve phenomenon is not found in aggregate level data. It is only found in the case of bilateral trade account with Japan, South Korea and Germany. 


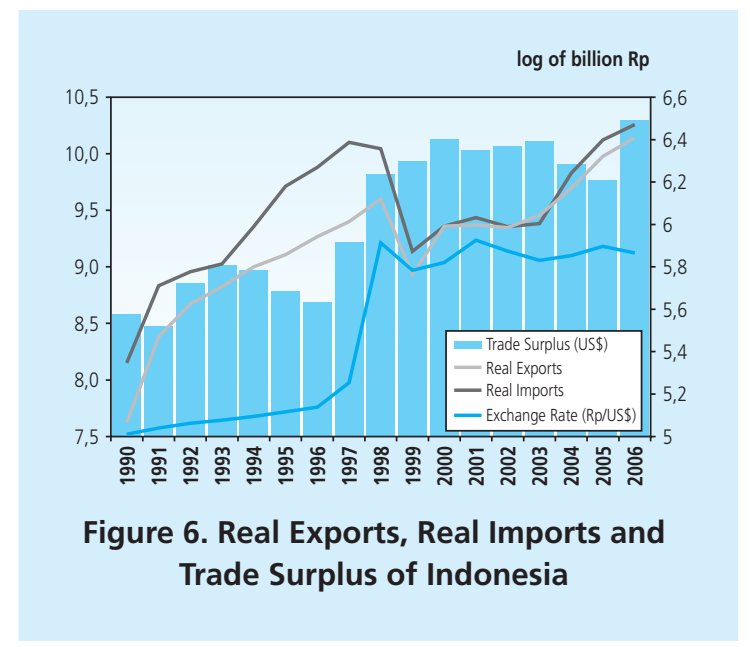

The movement of output, real import price and consumer inflation influence the following cyclical pattern of trade account. Real import rebounds as aggregate demand and output recovered and real import price lessens, resulting in a higher foreign price value of imports. Conversely, external demand for domestic goods decreases due to real exchange rate appreciation leading to a lower foreign price value of exports. Trade surplus is lower than its initial level in the medium run and finally stabilizes in the long-run at a slightly lower level than the initial steady-state value.

Some factors affect trade surplus dynamic. Exchange rate depreciation affects the volume of imports more than that of export since import price is less rigid than domestic price of exported goods. Moreover, imports plunge by significantly more than an upsurge of export in the short-run owing to quite high import content in production structure. In addition, real import price elasticity of imports is higher than real exchange rate elasticity of exports so that the sum of the elasticity is less than unity. The last factor explains why Marshall-Lerner condition does not hold. Hence the shock to the risk premium could worsen trade balance in the long term. Unlike this model simulation's result, Husman (2005) suggested that Marshall-Lerner condition is satisfied in the overall sample, implying the Rupiah's depreciation will increase the Indonesia exports in the long-run. She further found that although Marshal-Lerner condition is satisfied, exchange rate elasticity of bilateral trade account is quite small. One percentage change of real exchange rate only increases export to import ratio by $0.37 \%$. Different finding regarding Marshall-Lerner condition might imply an overestimated price elasticity of imports or underestimated price elasticity of exports assumed in this study. 

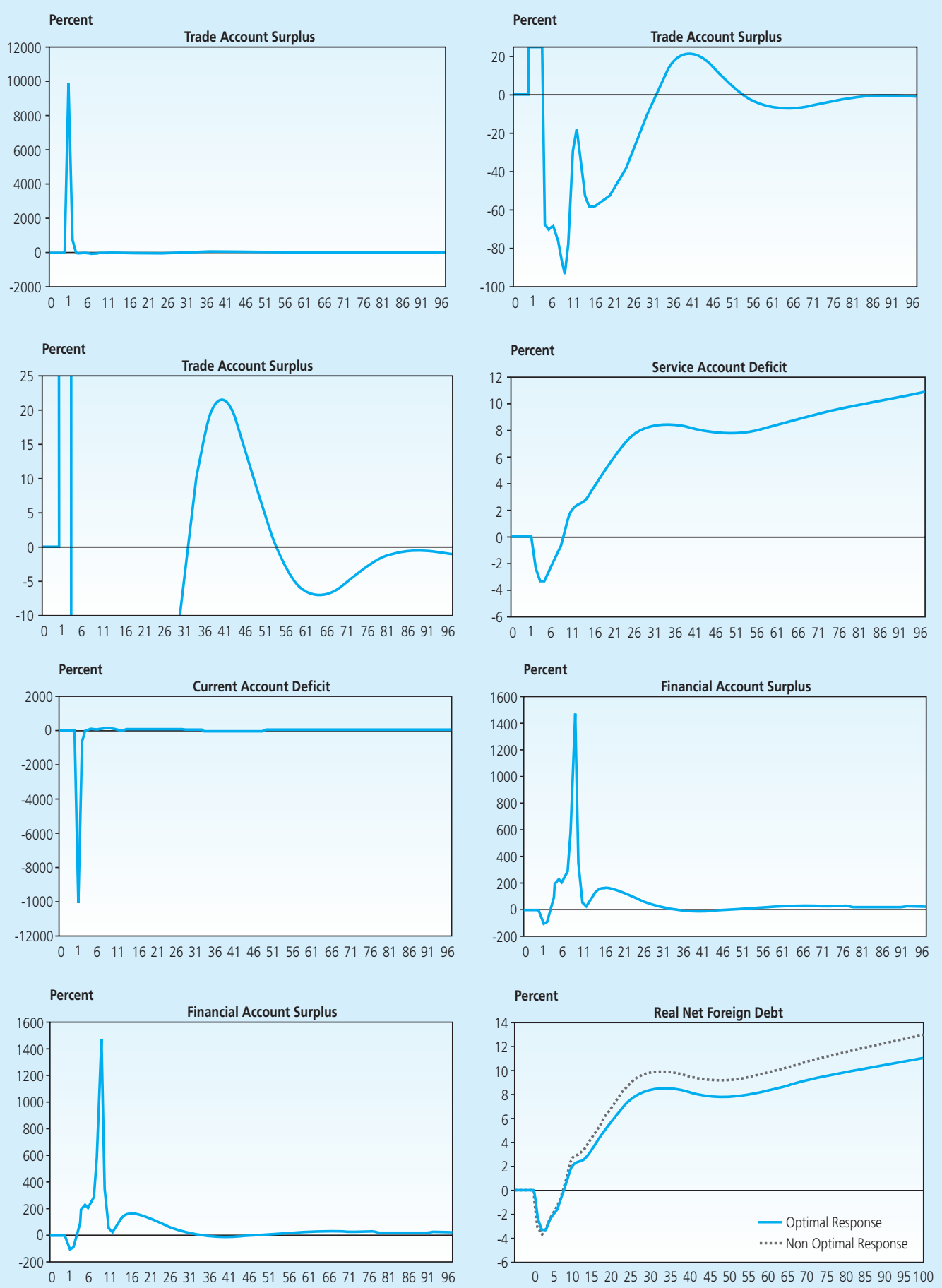

Figure 7. Responses of Balance of Payment Components on the eight-quarter one percentage point shock to the risk premium

(percent or percentage point deviation from baseline initial steady-state) 
Short-run improvement of trade account surplus enables the economy to reduce its net foreign debt. Afterwards, as trade account surplus worsens in the medium run and at last stabilises below its initial steady-state level, the economy has to increase net foreign debt continuously in the long-run. In line with net foreign debt's dynamics, service account deficit improves in the short-run then is getting worse in the long-run, diverging from the initial steady-state level. Overall, deficit current account lessens in the short-run because a better trade account surplus is enhanced by a smaller service account deficit. Ultimately, current account deficit becomes stable in the long-run at a worse level. Financial account surplus decreases in the short-run, then increases in the medium-run and finally reaches a higher steady-state surplus in the long-run.

\subsection{Demand for and Supply of Input and Output}

Aggregate demand channel of interest rate policy works through exports, consumption and investment. Consumption drops off contemporaneously as the expected lower future consumption outweighs a small decrease in current real interest rate. It further decreases in
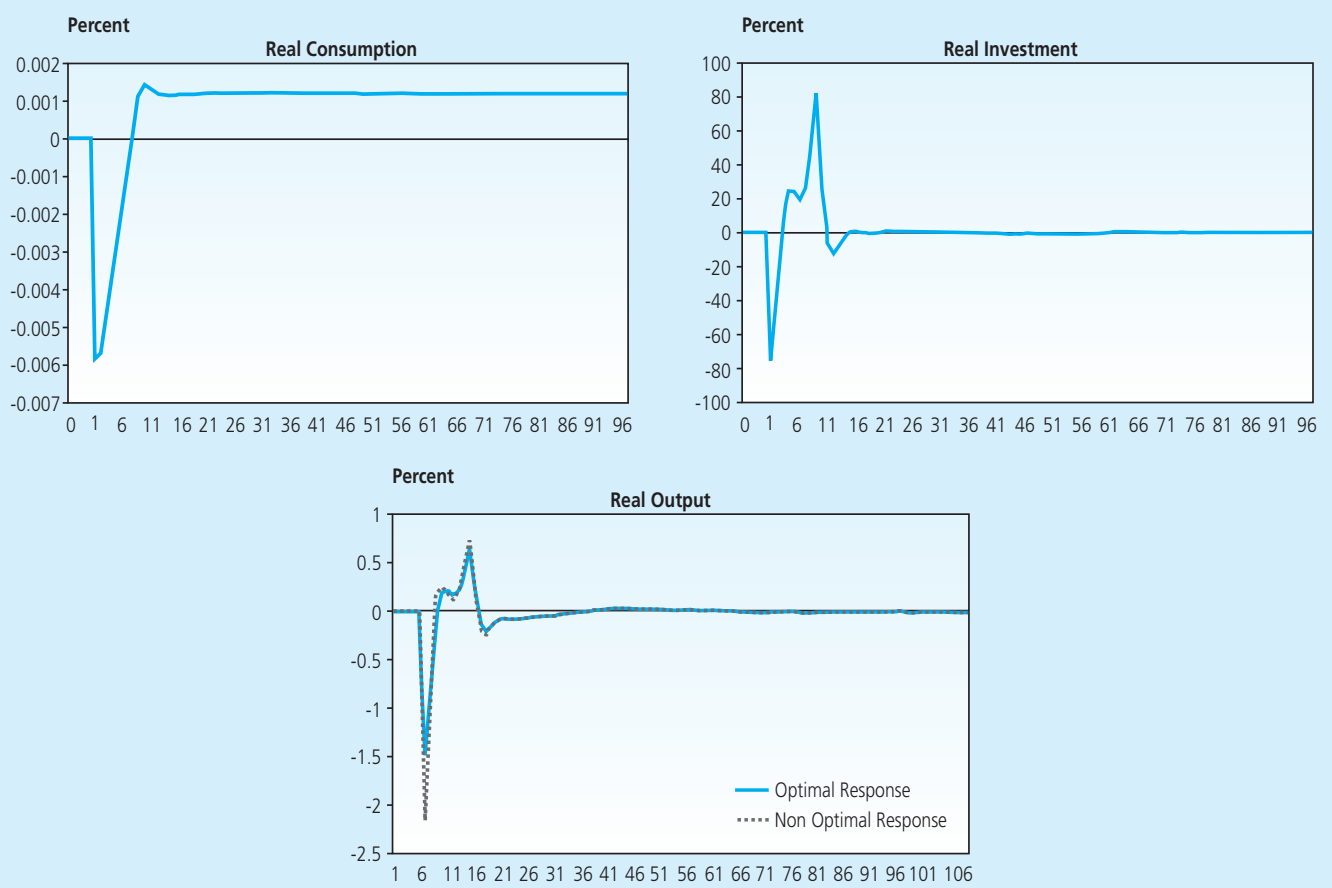

Figure 8. Responses of demand for and supply of output on an eight-quarter one percentage point shock to the risk premium

(percent or percentage point deviation from baseline initial steady-state) 

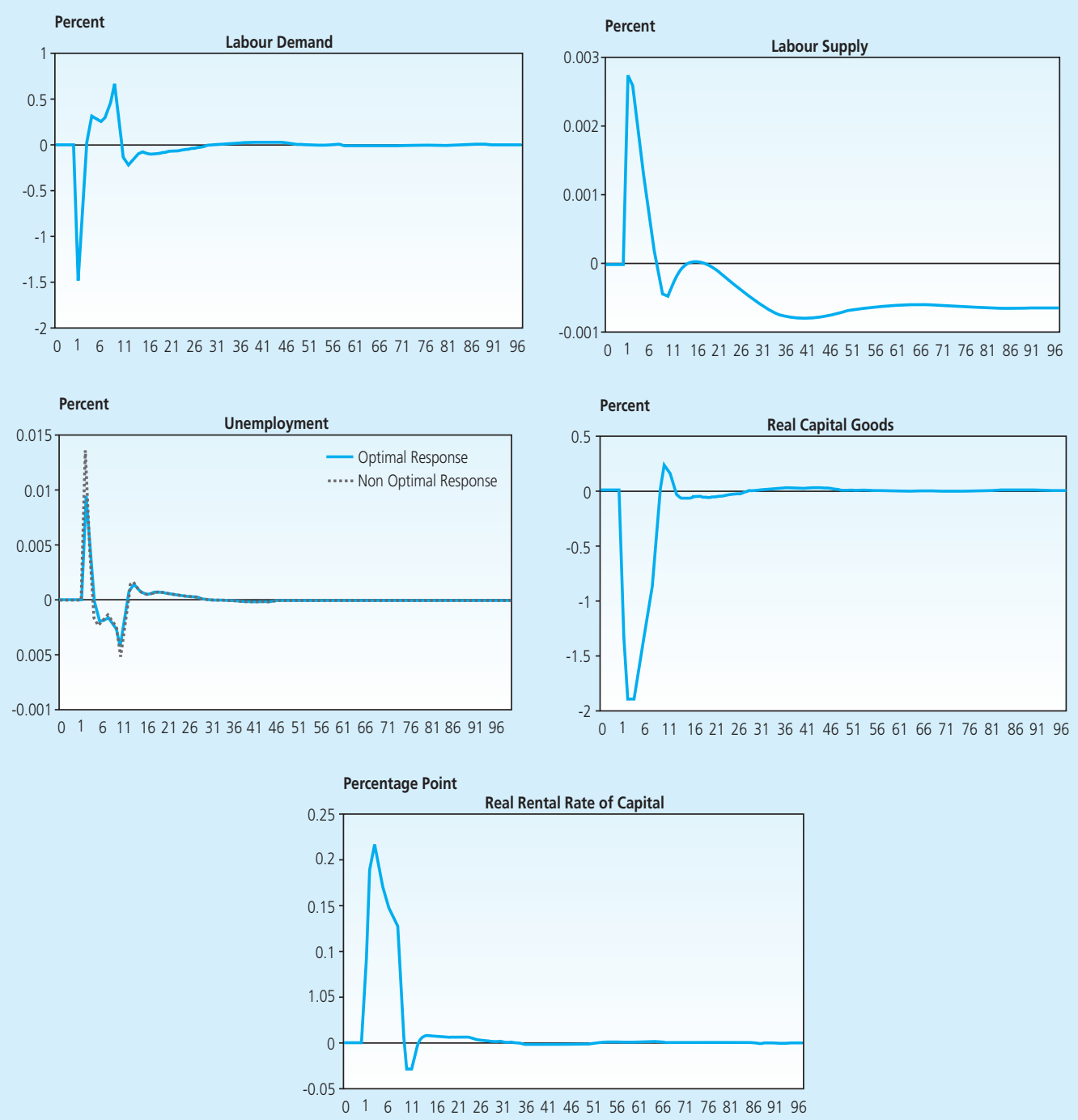

Figure 9. Responses of demand for and supply of input on an eight-quarter one percentage point shock to the risk premium

(percent or percentage point deviation from baseline initial steady-state)

several more periods as real interest rate increases in the following periods. When real interest rate stabilises in the long-run at a lower level than the initial steady-state, consumption stabilises at a higher new steady-state.

Demand for the stock of capital goods, to be utilized in the next period, falls when the shock to the risk premium hits the economy. Expected weakened aggregate demand in the following periods is behind the firm decision to ration its capital stock. This is often called as 
firm's balance sheet channel of interest rate to aggregate demand. A stronger external demand for domestic goods and domestic demand for domestic intermediate and final goods dampen investment demand contraction. The net effect is a fall in aggregate demand for domestic output in the wake of the shock. Thus, exchange rate depreciation triggered by a temporary shock to the risk premium is contractionary to output.

Demand for other factor inputs drops as well. As import price is less rigid, a depreciated real exchange rate leads to a more expensive real import price. Combined with a contemporaneous lowered aggregate demand, this strongly discourages demand for imported intermediate goods.

Employment falls because it is more affected by a much weakened aggregate demand than by a slightly more inexpensive real wage. This result is caused by unitary elasticity of labour demand with respect to real output and low elasticity of labour supply with respect to real wage.

\subsection{Costs, Prices and Inflations}

A squeezed labour demand brings downward pressure on real marginal cost of working. On the other side, leisure also decreases as demand for consumption goes down hence labour supply increases and puts a downward pressure on real marginal cost of working. Since nominal wage is quite rigid and highly indexed to its past inflation nominal wage is not responsive to changes in real marginal cost of working resulted from immediate adjustment in consumption and output.

Real wage declines because output price goes up and is more flexible than wage. Therefore, the immediate domestic inflation response to a lower aggregate demand is decreasing. In the following period of shock, investment starts to increase and consumption get stronger, causing upward pressure to the real marginal cost of working and wage inflation. Real wage is still below the initial steady-state level temporarily due to a more flexible output price than wage. Therefore, throughout the rest of shocks period the response of domestic inflation to a higher aggregate demand is decreasing.

Low real wage rigidity resulted from high nominal wage rigidity and low prices rigidity can be linked to a high real rigidity. Romer (2006) defines real rigidity as a low willingness of individual firm to change their relative price in response to changes in real output resulting from variations in real aggregate demand. A larger real rigidity corresponds to a greater consideration on competitor prices in price-setting behaviour. It means that when real rigidity is 

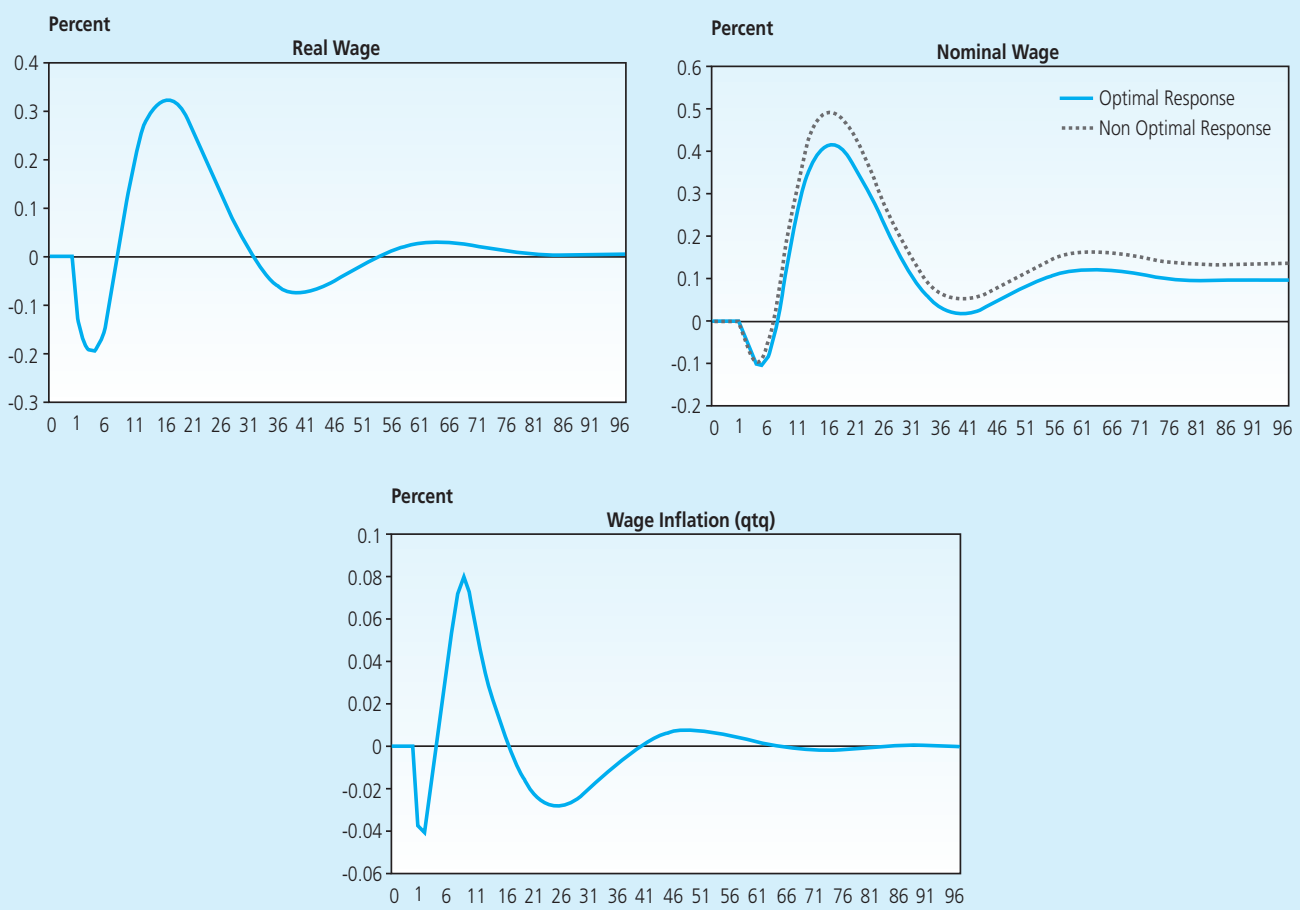

Figure 10. Responses of nominal and real wage on an eight-quarter one percentage point shock to the risk premium

(percent or percentage point deviation from baseline initial steady-state)

high each firm wants its price to move more closely with other prices. Bank Indonesia's business price setting survey (Darsono et al., 2002) revealed that cost-based approach is the most widely adopted price setting strategies among manufacturing and trading companies. The finding can justify the presence of price rigidities. It reflects the firm's reluctance to change prices when no cost changes occur. The survey also found that' 'cost plus variable profit margin' and "competitor prices' are the next most price setting methods used in manufacturing and retail firms, while 'market condition' is not the important factor in price setting policy. The survey results can be interpreted as low price rigidity in response to changes in cost and changes in competitor price. The latter means a high real rigidity ${ }^{5}$.

Risk-premium-induced exchange rate depreciation is passed-through to domesticallyproduced goods inflation using three channels. First, direct pass-through via cost of imported

5 Romer (2006) explains that, assuming the stylized aggregate demand curve, $\ln \mathrm{y}=\ln M-\ln P$ (where $M$ reflects factors that shift aggregate demand), real rigidity expression for the representative firm's profit-maximizing relative price, $\ln P_{i}^{*}-\ln P=\phi \ln y$, implies, $\ln P_{i}^{*}=\phi \ln M+(1-\phi) \ln P$ where high real rigidity is indicated by low $\phi$. 

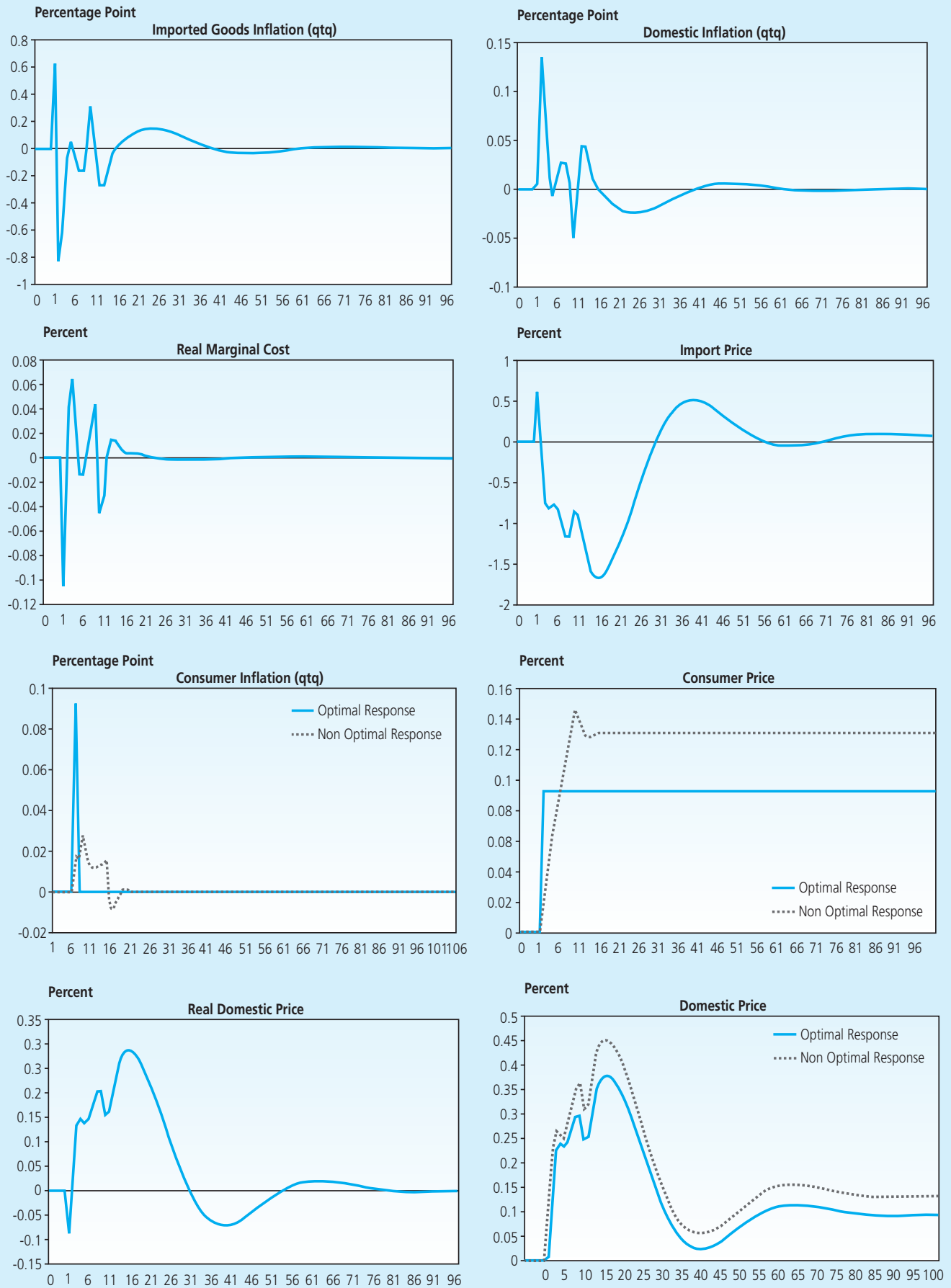

\section{Figure 11. Responses of prices on an eight-quarter one percentage point shock to the risk premium}

(percent or percentage point deviation from baseline initial steady-state) 
intermediate goods, which has an increasing effect on domestic inflation. Second, indirect pass-through via demand for imported input, which has a decreasing effect on domestic inflation. Third, indirect pass-through via external demand for domestic output. The latter has a decreasing effect on domestic inflation as well since an increased exports put small upward pressure on the rigid wage. Thus, with less rigid output price, it causes a decline in real cost of employment.

A direct cost-push pass-through of exchange rate to domestic inflation strongly dominates its demand side pass-through because of several factors. Firstly, high import content in production structure. Secondly, low real exchange rate elasticity of exports. Thirdly, high nominal wage rigidity, meaning low aggregate demand elasticity of wage inflation. Fourthly, a real import price elasticity of demand for imported intermediate goods. Exchange rate pass-through to consumer inflation is even higher as it is a combination of net cost-push pass-through to domestic inflation and direct cost-push pass-through of imported consumption goods to consumer inflation.

Large weight on cost of capital reflects a strong cost channel of interest rate policy, which gives an upward pressure to domestic inflation. It amplifies the strong pass-through extent of risk-premium-induced exchange rate depreciation to a higher domestic price.

\subsection{Tax and Government Debt}

As a consequence of smaller aggregate demand and higher interest rate the government faces a reduced tax base and a higher interest payment on the existing debt. Thus, the fiscal authority needs to raise tax rate and increases debt financing to keep its consumption expenditure constant amid pressure from a rising primary deficit. Since tax rule responds to primary deficit, a higher debt interest payment has no strengthening effect on tax increase. Accordingly, government debt is sustainable but the economy needs a longer time to bring down government debt toward its initial path.

An increase in tax rate has a tiny effect in dampening down inelastic labour supply, causing a slight upward pressure on real marginal cost of working. However, its pass-through to wage is in a much smaller magnitude since wage is quite rigid but indexed to inflation. As output price is more flexible than wage, the immediate domestic inflation response to a higher interest rate through aggregate labour supply channel of interest rate policy is decreasing but exceedingly weak. 

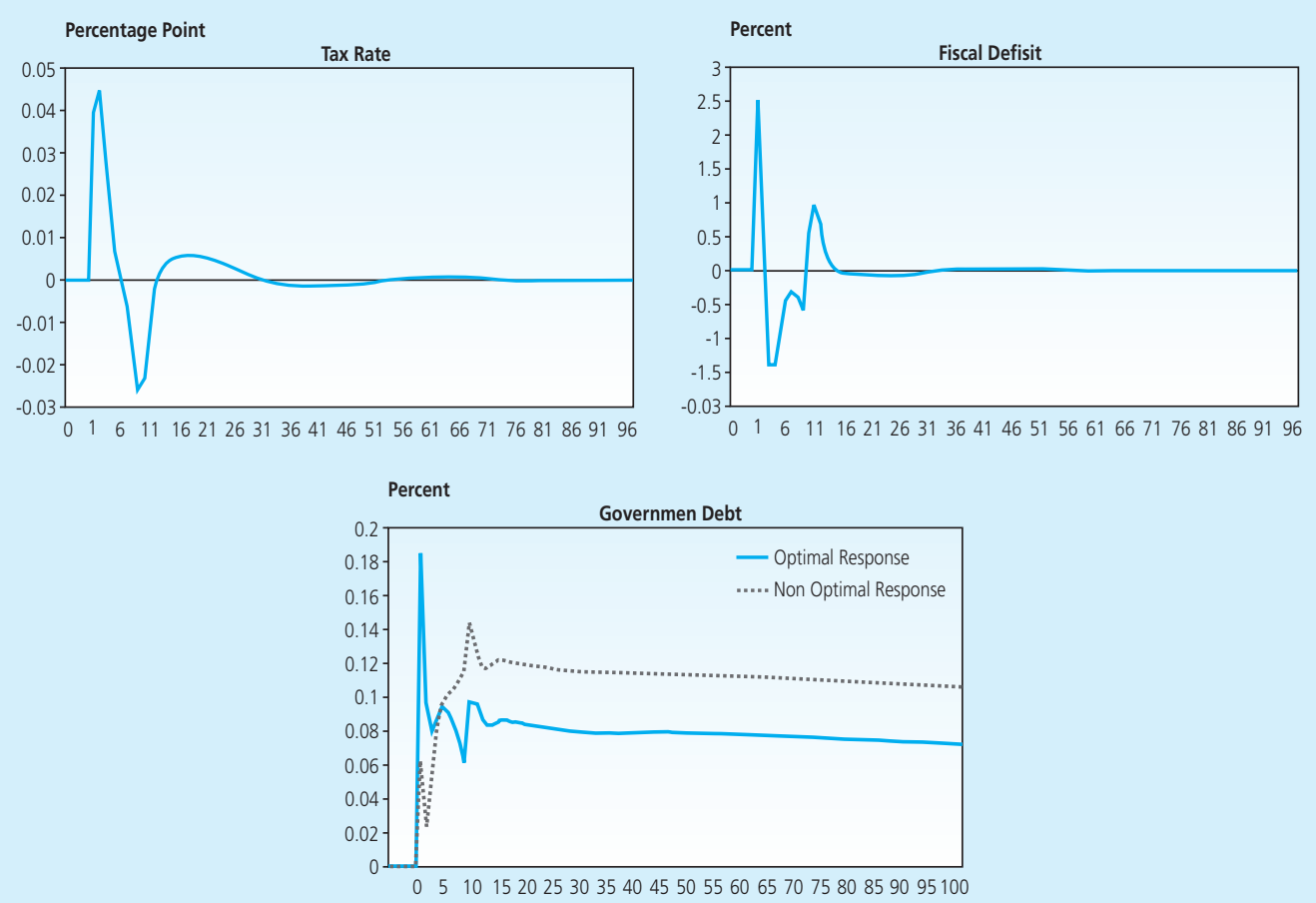

Figure 12. Responses of tax, government debt and fiscal deficit on an eight-quarter one percentage point shock to the risk premium

(percent or percentage point deviation from baseline initial steady-state)

\subsection{Interest Rate}

The model recommends the central bank to raise per annum interest rate up to the level that is 1.33 percentage points higher than the initial rate in one year after the initial shock. It then needs to be lowered but stays above the steady-state values for nine quarters, before finally stabilizes around the initial rate of $7 \%$. This interest rate response results in 0.09 percentage point jump in year-on-year consumer inflation. As nominal interest rate increases by more than an increase in consumer inflation, ex ante real interest rate goes up temporarily up to a level that is 1.27 percentage points above the initial steady-state rate of $2 \%$.

It is important to highlight the impact of implementing nonoptimal monetary policy response, which corresponds to the highest interest rate increase among the feasible response parameter. Such policy response results in a worse state of the economy in short-run: a higher nominal interest rate, more persistent consumer inflation, deeper output contraction, more unemployment, higher money balance and more expensive prices and wage. The economy also worse off in the long-run from more depreciated nominal exchange rate, more 

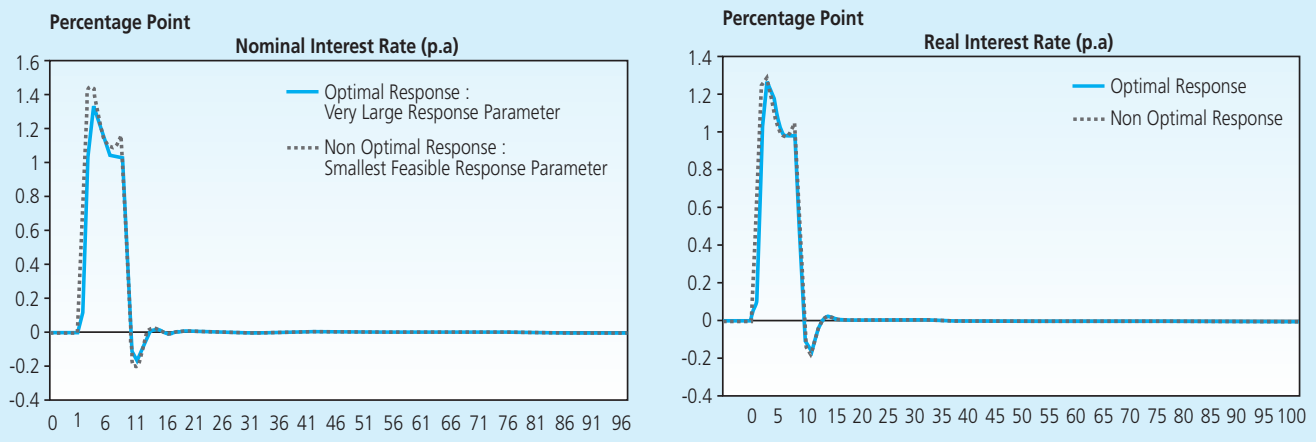

Figure 13. Responses of interest rate on an eight-quarter one percentage point shock to the risk premium

(percent or percentage point deviation from baseline initial steady-state)

expensive prices and wage, higher net foreign debt, higher government debt, larger real money balance, smaller trade account surplus, larger current account deficit and larger financial account surplus.

This simulation reveals how strong the cost channel of monetary policy is. Interest rate increases results in an upward pressure on domestic inflation through an increased cost of capital. The main source of downward pressure to domestic and consumer inflation is a decreasing real cost of importing goods caused by appreciated exchange rate in the economy that features a more flexible import price than domestic price and high import content. Strong cost channel of interest rate policy, more rigid wage than output price and high wage indexation to its past inflation account for lack of response of consumer price disinflation to interest rate increases. This is in line with the properties of small macroeconometric model of Bank Indonesia that predicts a weak power of interest rate tightening in lowering consumer inflation. It suggests that one percentage point increase in interest rate can only reduce consumer inflation by around 0.06 percentage point.

\subsection{Money Balance}

Real money demand, which is the opportunity cost of holding money by giving up both consuming goods and having return on money, falls off in the short-run and achieves a higher steady-state value in the long-run. The immediate response is not owing to the interest rate rise but rather simply follows the pattern of real consumption. This is due to a high real consumption elasticity of real money demand of despite small changes in consumption. On the other hand, low nominal interest rate elasticity of real money demand () dampens down the effect of relatively 

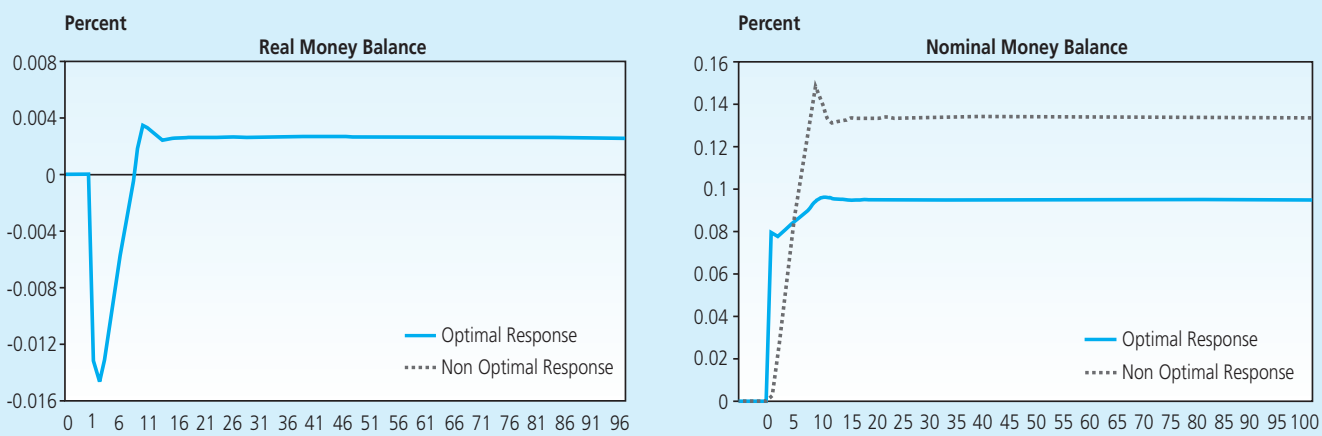

Figure 14. Responses of money balance on an eight-quarter one percentage point shock to the risk premium

(percent or percentage point deviation from baseline initial steady-state)

large interest rate increase. Therefore, a weakened demand for consumption goods strongly lowers demand for money holding.

Short-run fall in real money demand is less than consumer price increases. Therefore, when the central bank responds to the risk premium shock by raising interest rate nominal money supply has to be higher to clear money market. In this case, the direction of money and interest rate is contradictory, in the sense that monetary policy is tight in terms of interest rate but loose in terms of money supply.

\begin{tabular}{c|c|c} 
& $\begin{array}{c}\text { Table 2. } \\
\text { Correlation between currency growth and interest rate } \\
\text { Period }\end{array}$ & \multicolumn{2}{|c}{ Coefficient of correlation } \\
\cline { 2 - 3 } & 1-month SBI rate & 3-month deposit rate \\
\hline 1990Q1-1997Q2 & $-0,33$ & $-0,65$ \\
1997Q3-1998Q4 & 0,84 & 0,42 \\
1999Q1-2007Q1 & $-0,13$ & $-0,28$
\end{tabular}

Table 2 shows that interest rate became positively correlated with currency growth during currency crisis. However, the relation was partly due to a massive increase in liquidity support combined with a large increase in interest rate. Moreover, Figure 15 shows that an increase (a decrease) in Bank Indonesia interest rate policy (SBI rate), which is positively highly correlated with changes in deposit rate, does not necessarily slow down (speed up) the growth of currency in circulation over the post-crisis period. The negative correlation between interest rate and currency growth weakened during the period as shown in Table 2. Since money growth and 
policy interest rate could move in the same direction, the tightening or easing stance of monetary policy should, therefore, only be represented and clearly communicated by interest rate policy.

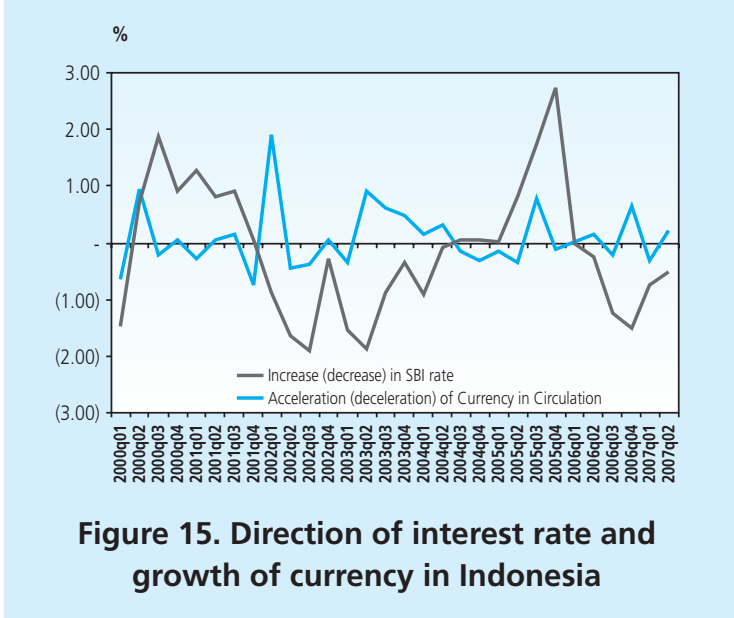

\section{CONCLUSION}

This study found that, even with optimal monetary policy response, a nominal exchange rate depreciation, triggered by a two-years shock to the interest risk premium, causes the economy to suffer in the short-run from a higher inflation, lower output, higher nominal and real interest rate, higher cost of capital, lower investment, higher government deficit and debt, higher tax rate, and higher unemployment.

The persistent shocks will also be worse for the economy in the long-run. It is characterised by a weaker long-run equilibrium of nominal exchange rate, more expensive domestic and imported prices and wage, and worse balance of payment (lower trade account surplus, higher current account deficit, higher capital inflow, larger net foreign debt, a higher but sustainable government debt). However, an appropriate monetary policy response, which is the smallest interest rate increases within the feasible set of interest rate responses, should manage to reduce such adverse effects.

Such property of shocks occurs because of lack of response of disinflation to increases in interest rate policy, which stems from the combination of high real rigidity, and strong cost channel of interest rates and exchange rate pass-through. Both aggregate demand channel of interest rates and demand-side channel of exchange rate pass-through have a weak effect on inflation.

Some policy implications might be appropriate. Such characteristics of monetary transmission complicate optimal monetary policy response. The central bank might be better 
pursuing a lower demand-induced inflation when adverse shock is nonexistent or in the presence of favourable supply shocks. When disinflation is successful, interest rate can, in turn, be lowered and finally helps reducing cost channel of interest rate and strengthen aggregate demand channel.

Since exchange rate shocks and cost-push shocks frequently harm the economy, other policies are necessary to complement monetary policy that can in turn help strengthen aggregate demand channel of monetary policy. The important thing is that the cost channel of interest rate needs to be weakened. It implies that the proportion of domestic income that goes to capital owner, investor or lender, should be reduced. Production structure switching, by increasing labour-intensive goods producers, could be a proper industrial policy to help reducing capital share of output.

Other possible policies are the ones that contribute to the reduction of cost of capital. This model and its simulation result are unable to suggest such policies that directly reduce cost of capital, as the absence of bank lending channel implies the equality of central bank policy rate and bank lending rate. However, when the channel exists, policy suggestions that encourage the reduction of financial intermediary's marginal cost and profit margin might be able to reduce physical capital cost. Other policies are the ones that help cutting nonmonetary-induced inflation that, in practice, will indirectly reduce cost of capital for a given real interest rate and spread between lending and deposit rate. In this study's modelling framework, the success of such policies will directly decrease both lending and policy rates. Given that price equals marginal cost plus profit margin, such policies are in the form of (i) reducing nonmonetary-induced marginal cost, (ii) decreasing profit margin, and (iv) enhancing profit margin flexibility to cost increases $^{6}$. Nonmonetary-induced marginal cost, which is not modelled in this study, might take the form of marginal cost of 'external labour' 7 and other determinants of marginal cost that are not included in marginal cost equation (equation 14).

Finally, it is important to address the model limitations that should be taken into account when interpreting the simulation result for policy purposes. This model is still deficient in its bank lending channel implying the absence of banks and that the central bank is part of the government. It would be interesting to find out how the economy reacts in the presence of bank as financial intermediary.

6 The price of domestically produced goods can be set as nominal marginal cost multiplied by gross profit margin, $P=M C^{d}(1+\mu)$, in which yakni $m c^{d}=m c^{d m}+m c^{d n m}$, where $m c^{d m}$ is monetary-induced real marginal cost, as in (14), is nonmonetary-induced real marginal cost and $\boldsymbol{\mu}$ is net profit margin.

7 Cost of 'external labour' is the extra cost firms have to spend persistently, for any reasons, for persons who are not the firm's employees or do not supply their labour in the form of production input. 


\section{REFERENCES}

Agénor, Pierre-Richard and Peter J. Montiel (2008). Development Macroeconomics, Third Edition. Princeton University Press.

Al-Eyd, Ali and Stephen G. Hall (2006). "Financial Crisis, Effective Policy Rules and Bounded Rationality in a New keynesian Framework". NIESR Discussion Paper No. 272.

Barth, M.J., Ramey, V. (2001). "The Cost Channel of Monetary Transmission". NBER Macroeconomic Annual, pp. 199-239.

Calvo, Guillermo (1983).-" Staggered Process in A Utility Maximizing Framework", Journal of Monetary Economics 12 (1983), pp. 89-100.

Chowdhury, Ibrahim, Mathias Hoffmanna, and Andreas Schabert (2006). "Inflation dynamics and the cost channel of monetary transmission". European Economic Review 50, pp. 9951016

Christiano, Lawrence J., Martin Eichenbaum, and Charles L. Evans (2005).-“Nominal Rigidities and the Effects of a Shock to Monetary Policy," "Journal of Political Economy, Vol. 113(1), $1 " 45$.

Clarida, R., J. Gali, M. Gertler (1999). "The Science of Monetary Policy: A New Keynessia Perspective". Journal of Economic Literature, Vol.37, Issue 4, 1661-1707.

Darsono, Akhis R. Hutabarat, Diah Esti Handayani, Hery Indratno, Retno Muhardini (2002). "Survey of Bussiness Price Setting Behavior". Paper presented at The $26^{\text {th }}$ CIRET Conference, Taipei, October 2002.

Drud, Arne (2006). "CONOPT", GAMS - The Solver Manuals, ARKI Consulting and Development A/S, Bagsvaerd, Denmark.

Eichenbaum, M. (1992). "Comment on 'Interpreting the macroeconomic time series facts: the effects'of monetary policy' by C.A. Sims". "European Economic Review, 36, pp. 1001-1011.

Erceg, Christopher J., Andrew T. Levin (1983). "Imperfect credibility and inflation persistence", Journal of Monetary Economics 50 (2003), pp. 915-955.

Hall, Simon, Mark Walsh, Anthony Yates (1997). "How do UK companies set prices?". Bank of England Working Paper 8905.

Hossain, A (2006). "Sources of Economic Growth in Indonesia, 1966-2003" Journal of Applied Econometrics and International Development, Vol.6 Issue 2. 
Husman, Jardine A. (2005). "Pengaruh Nilai Tukar Riil Terhadap Neraca Perdagangan Bilateral Indonesia: Kondisi Marshall-Lerner dan Fenomena J-Curve". Buletin Ekonomi Moneter dan Perbankan Bank Indonesia (Volume 8 No.3).

Hutabarat, Akhis R. (2007). "Monetary policy response to transient exchange rate and cost shocks". Working Paper, University of Leicester." Unpublished.

Murchison, Stephen, Andrew Rennison, and Zhenhua Zhu (2004). "A Structural Small OpenEconomy Model for Canada". Bank of Canada Working Paper 2004-4.

Ravenna, Federico, Carl E. Walsh (2006). "Optimal monetary policy with the cost channel". Journal of Monetary Economics Vol. 53, pp. 199-216.

Romer, D. (2006). Advanced Macroeconomics, 3rd edn. New York: McGraw-Hill.

Rosenthal, Richard E. (2006). "GAMS" - A User's Guide". GAMS Development Corporation, Washington, DC, USA

Sims, Christopher A. (1992). "Interpreting the macroeconomic time series facts: the effects of monetary policy". European Economic Review, 36, pp. 975-1000.

Smets, Frank, and Raf Wouters (2003). "An estimated stochastic dynamic general equilibrium model of the Euro area", ECB Working Paper No.171. Sorensen, Peter Birch, Hans Jorgen Whitta-Jacobsen (2005). "Introducing Advanced Macroeconomics - Growth and Business Cycles". The McGraw-Hill Companies.

Young, Alwyn (1995). "The Tyranny of Numbers: Confronting the Statistical Realities of the East Asian Growth Experience". The Quarterly Journal of Economics, Vol. 110, No.3, pp.641680.

Woodford, M (2003). "Interest and Prices. Foundations of a Theory of Monetary Policy". Princeton University Press.

Warjiyo, Perry and Juda Agung (2002). "Transmission Mechanisms of Monetary Policy in Indonesia", Bank Indonesia: Directorate of Economic Research and Monetary Policy. 
This page is intentionally left blank 